\title{
Growth and Development of Young Apple Fruits Following Applications of Ethephon Plus Carbaryl for Thinning
}

\author{
Daniel Ward ${ }^{1}$ and Richard P. Marini ${ }^{2}$ \\ Department of Horticulture, Virginia Polytechnic Institute and State University, \\ Blacksburg, VA 24061-0327 \\ Additional index words. Malus $\times$ domestica, fruit thinning, cellulase, abscission
}

\begin{abstract}
In three experiments, apple trees (Malus $\times$ domestica Borkh.) were sprayed, when fruits were 20 to $30 \mathrm{~mm}$ in diameter, with a combination of ethephon $\left(800 \mathrm{mg} \cdot \mathrm{L}^{-1}\right)$ and carbaryl $\left(600 \mathrm{mg} \cdot \mathrm{L}^{-1}\right)$ to induce abscission of all fruits on the tree. Two days after treatment (DAT), most treated fruits stopped or slowed increasing in diameter, fruit water potential was less negative, and starch accumulation was less than for nontreated fruits. Cellulase activity appeared in the abscission zone by 4 DAT. Fruit growth cessation following treatment was probably due to inadequate assimilate supplied to the fruit, but assimilate flow slowed before cellulase activity was apparent in the abscission zone. Chemical names used: 2-chloroethyl phosphonic acid (ethephon); 1-naphthyl ( $N$-) methylcarbamate (carbaryl).
\end{abstract}

Apple trees are chemically thinned to reduce excessive crop loads and encourage flower bud formation. The mechanism(s) by which thinners cause fruit abscission has been investigated for a number of years and several hypotheses have been tested. The hypothesis with the most supporting evidence is that thinning chemicals somehow interfere with translocation of carbohydrates to the fruit. Knight (1983) suggested that carbaryl causes abscission by reducing the movement of metabolites to the fruit or by increasing the competition for metabolites among the sinks, such as fruits and shoots. This hypothesis is supported by the work of Byers et al. (1985), which demonstrated that shading trees or spraying trees with photosynthetic inhibitors induced abscission of apple and peach [Prunus persica (L.) Batch.] fruits. Polomski et al. (1988) found that shading or spraying apple trees with terbacil(3-tert-butyl-5-chloro-6-methyluracil) generally reduced fruit dry weight and levels of total nonstructural carbohydrates and sugars. However, whether carbohydrate accumulation in the fruits was reduced before or after fruits stopped growing was not established. Young apple fruits stop growing several days before abscission (Byers et al. 1991; Schumacher, 1962, cited by Wertheim, 1971), and growth cessation is used by commercial apple growers to assess potential fruit drop before and after thinner applications (Marini, 1998).

\footnotetext{
Received for publication 15 Dec. 1998. Accepted for publication 9 Mar. 1999. The cost of publishing this paper was defrayed in part by the payment of page charges. Under postal regulations, this paper therefore must be hereby marked advertisement solely to indicate this fact.

${ }^{1}$ Graduate Student.

${ }^{2}$ Professor; to whom reprint requests should be addressed. E-mail: Marinirp@ vt.edu
}

Application of naphthalene acetic acid (NAA) reduced $\mathrm{CO}_{2}$ assimilation by apple leaves (Stopar et al., 1997). Benzyladenine [ $N$-(phenylmethyl)-1H-purine-6-amine; BA] promoted translocation of $\mathrm{C}^{14}$-sorbitol from apple leaves to the fruit when applied to the fruit, but not when applied to the leaves (Yuan and Greene, 1997). Assimilation of $\mathrm{CO}_{2}$ was reduced and dark respiration was increased when temperature following BA application was high, but there was no effect when temperature was low (Yuan and Greene, 1997).

Ward et al. (1999) recently detected cellulase activity in the abscission zone of apple fruits several days after the fruits were induced to drop by cutting the fruits in half. Therefore, reduced translocation of assimilates into fruits following thinning treatments may result from deterioration of the vascular connections in the abscission zone.

The objectives of this study were to: 1) determine if cellulase activity is present in the abscission zone before or after fruit growth cessation is induced by application of chemical fruit thinners; 2) identify the sequence of changes in several fruit properties following thinner application; and 3) determine if there are physiological changes other than growth cessation, such as starch accumulation, that commercial fruit growers can use to evaluate the efficacy of initial thinning treatments in time to apply a second treatment.

\section{Materials and Methods}

Three experiments were conducted in 1997; the experimental design, treatments, and data collection were the same for all experiments. The first experiment was conducted on 6-yearold 'Smoothee Golden Delicious'/M.27 trees. Treatments were applied on 28 May, when mean fruit diameter was $19.5 \mathrm{~mm}$. The second experiment was conducted on 9-year-old 'Golden Delicious' (Gibson strain)/M.9 and treatments were applied on 1 June when mean fruit diameter was $20.9 \mathrm{~mm}$. The third experiment was performed on 5-year-old 'Triple Red Delicious'/M.9. Treatments were applied on 4 June, when mean fruit diameter was 27.1 $\mathrm{mm}$. Five trees were sprayed to runoff with a hand-held sprayer with ethephon $\left(800 \mathrm{mg} \cdot \mathrm{L}^{-1}\right)$ plus carbaryl $\left(600 \mathrm{mg} \cdot \mathrm{L}^{-1}\right)$ plus Tween 20 (polyoxyethylene sorbitan monolaurate) (125 $\left.\mathrm{mL} \cdot \mathrm{L}^{-1}\right)$. These high concentrations were intended to cause all fruits on the treated trees to abscise. Five trees of each cultivar were not sprayed and served as controls. Treatments were applied when fruits were relatively large so the "June-drop" would be complete and fruit abscission during the experiment would be the result of the treatments. Previous experience indicated that the these treatments would remove most fruit $<30 \mathrm{~mm}$ in diameter (unpublished data).

For the 'Smoothee' experiment only, 10 king fruits on clusters with side fruits were tagged on each tree and fruit diameters were measured daily. For each experiment, at 2, 4, and $6 \mathrm{~d}$ after treatment (DAT), six fruiting spurs, each with three to five fruit, were harvested from each tree and the 30 spurs from each treatment were placed in a plastic bag, placed on ice, and transported to the laboratory. All but one fruit were detached from each spur. These fruit, with intact pedicels, were placed in a bag. Ten fruits from this pooled sample were randomly selected for water potential measurements with a pressure bomb (Scholander et al., 1965). The same fruits were then cut in half, transversely across the seed cavity, and the stem-end was placed in $\mathrm{I}_{2} / \mathrm{KI}$ solution for $30 \mathrm{~s}$ and starch was rated on a scale of 1 to 9 , where 1 = stain across the entire surface and $9=$ no stain. Ten additional fruit, selected from the pooled sample, were weighed, the diameters were measured in two directions, $90^{\circ}$ from each other, and the fruit were used for respiration determination. The 10 fruits were randomly assigned to five pairs and each two-fruit sample was enclosed in a 473$\mathrm{mL}$ glass chamber with an airflow rate of 20 $\mathrm{mL} \cdot \mathrm{s}^{-1}$. The difference in $\mathrm{CO}_{2}$ concentration of air entering and exiting the chamber was measured with an Analytical Development Corp. (P.K. Morgan Instruments, Andover, Mass.) $\mathrm{CO}_{2}$ analyzer (model LCA-2). The fruits were then dried at $70^{\circ} \mathrm{C}$ for $72 \mathrm{~h}$ and dry weights were recorded. The fresh and dry weights were used to calculate the percentage of dry matter in each fruit.

The 10 fruits still attached to the spurs were used to assess cellulase activity in the abscission zone (Ward etal., 1999). Each fruit pedicelspur piece was cut to a length of $\approx 7 \mathrm{~mm}$, then cut longitudinally through the abscission region with a microtome blade. Thin layers $(\approx 2$ $\mathrm{mm}$ thick) of $6 \%$ agarose in $50 \mathrm{~mm}$ acetate buffer ( $\mathrm{pH}$ 5.2) were prepared in 6-cm square petri dishes. To detect cellulase activity, $0.2 \%$ carboxymethyl-cellulose was included as a substrate in the gel. The cut surface of the pedicel-spur junction was pressed gently against the gel for $1 \mathrm{~s}$. The plant tissue was removed and the plates were sealed and incubated at $37^{\circ} \mathrm{C}$ for $3 \mathrm{~h}$. Cellulase activity was 
visualized by staining the plates in a bath of $0.1 \%$ Congo Red for 30 min and destaining by rinsing several times with $1 \mathrm{M} \mathrm{NaCl}$. Areas of the gel where the substrate was hydrolyzed remained unstained. This technique does not allow quantification of cellulase activity, but simply indicates the presence or absence of enzyme activity.

The experiments were completely randomized designs. Because fruits were considered to be the experimental units, there were 10 replications per measurement time per treatment for most response variables. Because two-fruit samples were used to measure respiration, only five replicates were used for respiration data. To compare daily growth of 'Smoothee' fruits on the tree, data were analyzed with a multivariate repeated measures analysis with the GLM Procedure of SAS (SAS Institute, 1990). The Profile transformation was used to test the effect of treatment on the increase in fruit diameter from one day to the next. For most response variables, $t$ tests were performed on each date to compare equality of treatments. Because the data from the cellulase assay were binomial, treatments were compared with Fisher's chi square test.

\section{Results and Discussion}

Fruit abscission was not quantified, but observations indicated that $\approx 5 \%$ and $95 \%$ of the fruit on nontreated and treated trees, respectively, abscised within $14 \mathrm{~d}$ of treatment.

For 'Smoothee' the change in fruit diameter from 0 to 1 DAT was not significantly affected by treatment, but thereafter the daily increase in diameter was significantly less for treated fruits (Fig. 1). However, diameter, fresh weight, and dry weight of fruit removed from the trees were not consistently affected by the thinning treatment (Table 1). These apparently conflicting results may be due to differences in sample size or to differences in statistical analyses. There were also differing numbers of fruits per spur, which may have influenced fruit size and increased unexplained variation. Daily fruit size measurements on the tree were recorded for a total of 50 fruit per treatment, whereas measurements of fruit removed from the tree were recorded for only 10 fruit per treatment. Additionally, the profile contrasts from repeated measures analysis actually compare the change in fruit diameter from one day to the next rather than the fruit diameter on a given date. This type of analysis removes the variation due to differences in fruit diameter before treatments were applied. Polomski et al. (1988) reported that dry weight of terbacil-treated fruit was reduced at 5 DAT, but not at 2 DAT. Also reported were reductions in leaf $\mathrm{CO}_{2}$ assimilation and specific leaf weight, but not in fruit dry weight or total nonstructural carbohydrates $2 \mathrm{~d}$ after terbacil applications. They also were unable to detect differences in dry weight 2 DAT, possibly because they removed and measured only 10 fruits from each of five trees per treatment. Because of the large fruit-to-fruit variation within trees, sub-sampling trees to evaluate relatively small changes in fruit size does not

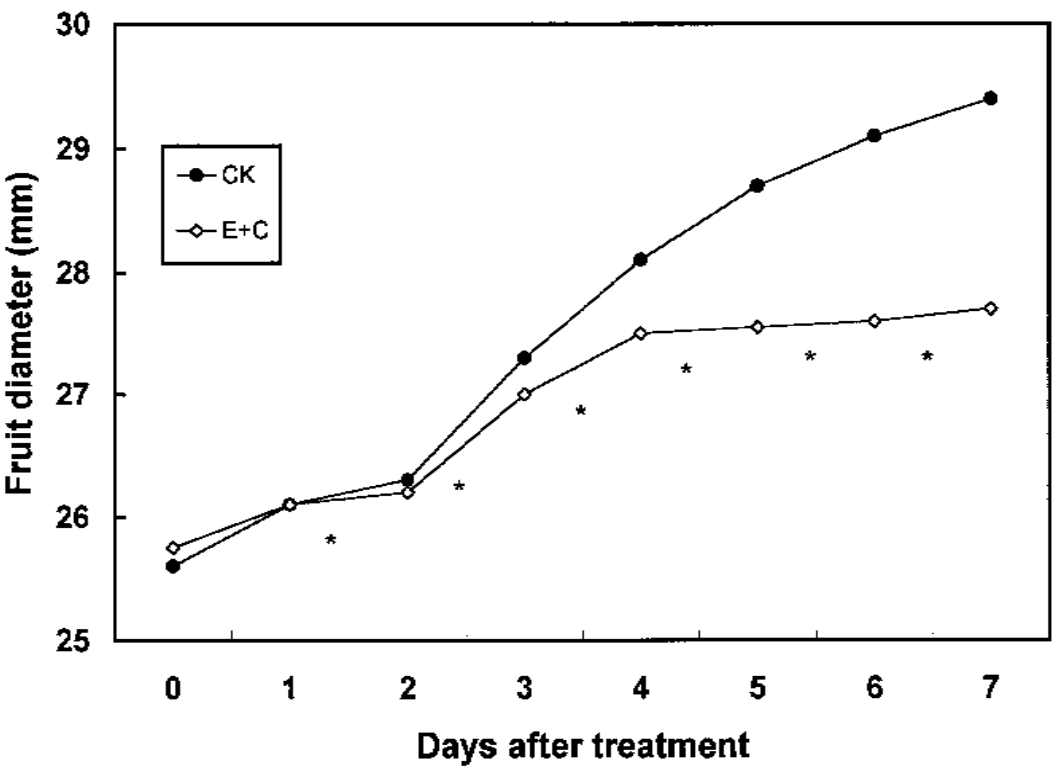

Fig. 1. The influence of ethephon plus carbaryl $(E+C)$ application on growth of 'Smoothee' fruits for $7 d$ after treatment. Data were analyzed with repeated measures analysis of variance and asterisks indicate that the change in fruit diameter from one measurement date to the next was significantly $(P<0.05)$ affected by treatment.
Table 1. Effects of application of ethephon plus carbaryl $(\mathrm{E}+\mathrm{C})$ on mean fresh weight $(\mathrm{FW})$, dry weight (DW), diameter, water potential $\left(\Psi_{\mathrm{w}}\right)$, starch index, respiration, percent dry matter (DM), and the percentage of fruits with cellulase activity (CA) of young apple fruits measured several days after treatment (DAT).

\begin{tabular}{|c|c|c|c|c|c|c|c|c|c|}
\hline $\begin{array}{l}\text { Time } \\
\text { (DAT) }\end{array}$ & Treatment & $\begin{array}{r}\text { FW } \\
(\mathrm{g})\end{array}$ & $\begin{array}{r}\text { DW } \\
(\mathrm{g})\end{array}$ & $\begin{array}{l}\text { Diam } \\
(\mathrm{mm})\end{array}$ & $\begin{array}{c}\Psi_{\mathrm{w}} \\
(\mathrm{MPa})\end{array}$ & $\begin{array}{l}\text { Starch } \\
\text { index }^{z}\end{array}$ & $\begin{array}{c}\text { Respiration } \\
\left(\mu \mathrm{mol} \cdot \mathrm{kg}^{-1} \cdot \mathrm{h}^{-1}\right)\end{array}$ & $\begin{array}{l}\mathrm{DM} \\
(\%)\end{array}$ & $\begin{array}{l}\text { CA } \\
(\%)\end{array}$ \\
\hline \multicolumn{10}{|c|}{ 'Smoothee' treated 28 May } \\
\hline \multirow[t]{3}{*}{2} & Control & 5.5 & 0.53 & 18.9 & -4.3 & 9.0 & 6.4 & 9.6 & --- \\
\hline & $E+C$ & 5.7 & 0.55 & 19.4 & -3.6 & 9.0 & 6.8 & 9.4 & --- \\
\hline & $P>F$ & 0.747 & 0.813 & 0.652 & 0.028 & 1.000 & 0.738 & 0.781 & \\
\hline \multirow[t]{3}{*}{4} & Control & 7.3 & 0.89 & 22.0 & -3.9 & 9.9 & 5.0 & 12.1 & 0 \\
\hline & $E+C$ & 7.1 & 0.89 & 21.5 & -2.0 & 9.0 & 5.7 & 12.5 & 50 \\
\hline & $P>F$ & 0.751 & 1.000 & 0.521 & 0.001 & 1.000 & 0.294 & 0.445 & 0.010 \\
\hline \multirow[t]{3}{*}{6} & Control & 8.8 & 0.97 & 23.8 & -3.2 & 6.6 & 10.9 & --- & --- \\
\hline & $\mathrm{E}+\mathrm{C}$ & 7.1 & 0.78 & 21.4 & -2.3 & 8.0 & 10.9 & --- & --- \\
\hline & $P>F$ & 0.083 & 0.146 & 0.084 & 0.012 & 0.016 & 0.909 & & \\
\hline \multicolumn{10}{|c|}{ 'Golden Delicious' treated 1 June } \\
\hline \multirow[t]{3}{*}{2} & Control & 8.3 & 0.90 & 23.3 & -4.7 & 5.5 & 3.3 & 11.3 & 0 \\
\hline & $E+C$ & 8.6 & 1.00 & 23.7 & -4.2 & 7.8 & & 12.2 & 10 \\
\hline & $P>F$ & 0.664 & 0.293 & 0.663 & 0.128 & 0.001 & 0.455 & 0.140 & 0.305 \\
\hline \multirow[t]{3}{*}{4} & Control & 9.1 & 1.10 & 24.4 & -6.2 & 5.9 & & 12.3 & 0 \\
\hline & $E+C$ & 6.7 & 1.10 & 23.5 & -3.5 & 7.9 & & 16.3 & 80 \\
\hline & $P>F$ & 0.034 & 0.706 & 0.492 & 0.001 & 0.004 & 0.026 & 0.001 & 0.001 \\
\hline \multirow[t]{3}{*}{6} & Control & 10.0 & 1.30 & 25.2 & -4.2 & 6.6 & 3.1 & 12.7 & --- \\
\hline & & 8.9 & 1.10 & 24.3 & -2.7 & 7. & & 12.4 & --- \\
\hline & $P>F$ & 0.368 & 0.272 & 0.400 & 0.001 & 0.146 & 0.758 & 0.488 & \\
\hline \multicolumn{10}{|c|}{ 'Delicious' treated 4 June } \\
\hline \multirow[t]{3}{*}{2} & Control & 10.3 & 1.70 & 29.1 & -5.3 & 6.1 & 3.3 & 16.6 & --- \\
\hline & $E+C$ & 9.0 & 1.60 & 28.0 & -4.5 & 7.1 & & 17.5 & --- \\
\hline & $P>F$ & 0.046 & 0.157 & 0.072 & 0.059 & 0.037 & 0.229 & 0.122 & \\
\hline \multirow[t]{3}{*}{4} & Control & 10.0 & 1.40 & 27.5 & -3.7 & 5.7 & 4.2 & 14.5 & 0 \\
\hline & $E+C$ & 9.0 & 1.40 & 26.2 & -2.4 & 7.1 & 3.0 & 15.2 & 10 \\
\hline & $P>F$ & 0.294 & 0.595 & 0.312 & 0.001 & 0.001 & 0.083 & 0.163 & 0.305 \\
\hline \multirow[t]{3}{*}{6} & Control & 12.4 & 1.60 & 29.5 & -3.7 & 4.9 & 4.4 & 12.8 & --- \\
\hline & $E+C$ & 8.4 & 1.20 & 25.6 & -1.9 & 6.0 & 3.3 & 13.7 & --- \\
\hline & $P>F$ & 0.009 & 0.030 & 0.009 & 0.001 & 0.146 & 0.072 & 0.066 & \\
\hline
\end{tabular}

${ }^{2}$ Starch was rated on a scale of $1=$ entire cut surface stained to $9=$ entire cut surface remained unstained. 
seem feasible unless a large number of fruit are sampled from each tree.

For 'Delicious', but not the other cultivars, fruit diameter, fresh weight, and dry weight were less for treated trees at 6 DAT than for control trees. In previous experiments, when the same fruit were measured daily, growth stopped 2 to 6 DAT (unpublished data). Based on our previous observations, the length of time from treatment to fruit growth cessation is probably related to fruit size at the time of treatment, weather conditions following treatment, and the choice of thinning chemicals. Percentage of fruit dry matter was rarely affected significantly, and was inconsistently affected by treatment (Table 1).

Water potential was consistently less negative for treated than for control fruit on all measurement dates (Table 1). Schneider(1977) also reported less negative leaf water potential following NAA application. Less starch was present in treated fruit, and in two of the three experiments some reduction was apparent 2 DAT. The effect of the treatment on fruit respiration was inconsistent and treatments differed significantly on only one date in one experiment. For 'Smoothee' and 'Golden Delicious', respiration tended to be higher for treated fruit, but the difference was significant for only 'Golden Delicious' at 4 DAT (Table 1). For 'Delicious', respiration was lower for treated fruit at 4 and 6 DAT $(P=0.083$ and 0.072 , respectively). Changes in fruit water potential and the lack of starch accumulation indicate a lack of assimilate in the treated fruits. Because respiration was not affected by the thinning treatment, reduced carbohydrates in the fruit likely resulted from reduced translocation. This conclusion is consistent with reports of reduced $\mathrm{CO}_{2}$ assimilation in treated leaves (Stopar et al., 1997) or reduced carbohydrate translocation to the fruits following thinning treatments (Schneider, 1978; Yuan and Greene, 1997).

Cellulase activity was evaluated at 4 DAT for all experiments (Table 1). Preliminary experiments in 1996 indicated that cellulase activity appeared $\approx 2 \mathrm{~d}$ after fruit ceased growth. To verify our previous observations, the cellulase assay was performed at 2 DAT for 'Golden Delicious'. Cellulase was not evaluated at 6
DAT because the pedicel tended to separate from the spur of treated fruit during sample preparation. In this study, cellulase activity was never observed in tissue from nontreated trees. Only one of the 10 treated 'Golden Delicious' spurs sampled 2DAT had cellulase activity. At 4 DAT, cellulase activity was present in 5, 8, and 1 spurs per 10-spur sample for 'Smoothee', 'Golden Delicious', and 'Delicious', respectively. These data indicate that cell wall degradation in the abscission zone is not responsible for fruit growth cessation, but cell walls are altered after changes occur in fruit growth and fruit water potential. Changes in the abscission zone, induced by cellulase activity, are probably not responsible for reduced translocation of metabolites into the fruit or reduced fruit growth. However, our data do not rule out the possibility that other changes in the abscission zone, not requiring cellulase activity, may precede fruit growth cessation.

Ethephon and carbaryl may have different modes of action as fruit thinners. Carbaryl may cause abscission by reducing export of photosynthates to the fruit (Knight, 1983), but the role of ethylene remains unresolved. The combination of ethephon plus carbaryl was used in this study because it is the only treatment we have found that consistently causes abscission of most fruit (Marini, 1996). Unfortunately, this combination of materials does not allow one to study the sequence of changes following the application of the individual materials.

Fruit growth cessation, probably resulting from inadequate supplies of carbohydrates, may occur shortly after application of the thinners. Cellulase activity appears in the abscission zone several days after fruit growth cessation, but several days before fruit abscission. Results from this study show that the first indications that a fruit is destined to drop during the early season is stoppage of growth and less negative fruit water potential. Daily fruit growth measurement, which is nondestructive and requires no expensive equipment, is the only practical method to assess results of initial thinning treatments in time to apply additional treatments in commercial orchards.

\section{Literature Cited}

Byers, R.E., D.H. Carbaugh, C.N. Presley, and T.K Wolf. 1991. The influence of low light on apple fruit abscission. J. Hort. Sci. 66:7-17.

Byers, R.E., C.G.Lyons, Jr., K.S. Yoder, J.A. Barden, and R.W. Young. 1985. Peach and apple thinning by shading and photosynthetic inhibition. J. Hort. Sci. 60:465-472.

Knight, J.N. 1983. Translocation properties of carbaryl in relation to its use as an apple fruitlet thinner. J. Hort. Sci. 58:371-379.

Marini, R.P. 1996. Chemically thinning spur 'Delicious' apples with carbaryl, NAA, and ethephon at various stages of fruit development. HortTechnology 6:241-246.

Marini, R.P. 1998. Apple thinning in 1998. Virginia Fruit 86(2):1-3.

Polomski, R.F., J.A. Barden, R.E. Byers, and D.D.Wolf. 1988. Apple fruit nonstructural carbohydrates and abscission as influenced by shade and terbacil. J. Amer. Soc. Hort. Sci. 113:506-511.

SAS Institute. 1990. SAS/STAT user's guide, ver. 6,4 th ed. SAS Inst., Cary, N.C.

Schneider, G.W. 1977. Studies on the mechanism of fruit abscission in apple and peach. J. Amer. Soc. Hort. Sci. 102:179-181.

Schneider, G.W. 1978. Abscission mechanism studies with apple fruitlets. J. Amer. Soc. Hort. Sci. 103:455-458.

Scholander, P.F., H.T. Hammel, E.D. Bradstreet, and E.A. Hemmingsen. 1965. Sap pressure in vascular plants. Science 148:339-346.

Schumacher, R. 1962. Fruchtentwicklung und Blütenknospenbildung beim Apfel in Abhangigkeit von der Blättmasse, unter Berücksichtigung der abwechselnden Tragbarkeit. Schweiz. Landw. Forsch. 1:361449. (Cited by Wertheim, 1971.)

Stopar, M., B.L. Black, and M.J. Bukovac. 1997. The effect of NAA and BA on carbon dioxide assimilation by shoot leaves of spur-type 'Delicious' and 'Empire' apple tree. J. Amer. Soc. Hort. Sci. 122:837-840.

Ward, D.L., E.P. Beers, R.E. Byers, and R.P. Marini. 1999. Cutting apple fruits induces cellulase activity in the abscission zone. HortScience 34:601603.

Wertheim, S.J. 1971. The drop of flowers and fruits in apple, with special reference to the June drop of Cox's Orange and its control with growth regulators. Meded. Landbouwhogeschool Wageningen, The Netherlands, 71-17.

Yuan, R. and D.W. Greene. 1997. Effect of benzyladenine (BA) on fruit thinning and carbohydrate status in apples. HortScience 32:525 (Abstr.). 